\title{
Glosa do WYROKU WojeWódZKIEgo SĄDU AdMinistracYJNEgo W BYdgoszCZY Z DNIA 5 LUTEGO 2020 R., SYGN. I SA/BD 732/19
}

Streszczenie. Glosowany wyrok Wojewódzkiego Sądu Administracyjnego dotyczy przede wszystkim zakresu pojęcia „podatnik VAT” przy sprzedaży nieruchomości oraz problemów pojawiających się w praktyce w związku z działaniami podjętymi przez sprzedającego. Autor dokonuje krytycznej analizy tezy postawionej w orzeczeniu oraz porusza problematyczne zagadnienia związane $\mathrm{z}$ aktywnością sprzedającego podejmowaną w celu podniesienia wartości lub uatrakcyjnienia nieruchomości.

Słowa kluczowe: podatek VAT przy sprzedaży nieruchomości, pojęcie i przesłanki podatnika VAT, profesjonalna i zorganizowana aktywność sprzedającego nieruchomość

Teza: Status prawny sprzedającego nieruchomość jest zależny od podejmowanych przez niego działań. Działania mające na celu podział nieruchomości lub zmianę jej przeznaczenia przy jednoczesnym korzystaniu z usług biura pośrednictwa nie powinny być uznawane za przejaw profesjonalnej i zorganizowanej aktywności sprzedającego, jeżeli nie zostały spełnione pozostałe przesłanki pojęcia „podatnik VAT” w zakresie sprzedaży

* Student, Wydział Prawa i Administracji Uniwersytetu Łódzkiego, e-mail: rafal.graczyk.23@gmail.com 
nieruchomości. Zalicza się do nich również sposób i cel nabycia nieruchomości, sposób sprzedaży, a także działania związane z uatrakcyjnieniem nieruchomości. Dopiero po łącznym uwzględnieniu wszystkich przesłanek można rzetelnie dokonać wykładni pojęcia „podatnik VAT” przy sprzedaży nieruchomości w konkretnym stanie faktycznym sprawy.

1. Glosowane orzeczenie Wojewódzkiego Sądu Administracyjnego (WSA) w Bydgoszczy z dnia 5 lutego 2020 r. ${ }^{1}$ dotyczy zakresu pojęcia „podatnik podatku VAT” przy sprzedaży nieruchomości oraz trudności pojawiających się w praktyce w związku z działaniami podjętymi wobec tej nieruchomości przez sprzedającego.

W sprawie objętej wskazanym powyżej orzeczeniem Skarżąca złożyła wniosek o wydanie interpretacji indywidualnej. We wniosku opisała stan faktyczny, zgodnie z którym nabyła odpłatnie w latach 2001, 2006, 2007 i 2009 łącznie 13 ha gruntów rolnych, od 2006 r. prowadzi działalność rolną, a także wykonuje działalność gospodarczą w zakresie prowadzenia biura rachunkowego.

Nieruchomości, które są objęte zakresem sprawy, zostały podzielone na 42 działki o powierzchniach od 1500 do $3000 \mathrm{~m}$ kw. Z działek wydzielono osobny teren stanowiący drogę dojazdową.

Ze względu na brak miejscowego planu zagospodarowania przestrzennego Skarżąca we własnym imieniu wystąpiła dla części z nich o wydanie decyzji o warunkach zabudowy i wskazuje, że przed sprzedażą również dla pozostałych działek zamierza wystąpić o wydanie takiej decyzji.

Skarżąca wskazała, że grunty wchodzą w skład jej majątku prywatnego oraz że koszty związane $\mathrm{z}$ dokonaniem podziału nieruchomości i wydaniem decyzji o warunkach zabudowy poniosła jako osoba fizyczna i nie odliczała z tego tytułu podatku VAT.

Skarżąca ponadto zaznaczyła we wniosku, że nie wykonywała żadnych działań związanych z doprowadzeniem wody lub prądu do poszczególnych działek oraz nie wykonywała żadnych prac ziemnych i ulepszeń, które mogłyby mieć wpływ na atrakcyjność działek.

Strona uzupełniała opisany stan faktyczny, podając, że nie dokonywała dostawy produktów rolnych pochodzących z własnej działalności rolniczej

1 Wyrok WSA w Bydgoszczy z dnia 5 lutego 2020 r., sygn. I SA/Bd 732/19, LEX nr 2925814. 
lub świadczenia usług rolniczych dla innych osób i działalności, oraz opisując rzeczywisty sposób korzystania z przeznaczonych nieruchomości.

Dyrektor Krajowej Informacji Skarbowej, na podstawie stanu faktycznego zawartego we wniosku Skarżącej, wydał interpretację indywidualną, zgodnie z którą mimo okoliczności przez nią wskazanych jest ona uważana za podatnika podatku od towarów i usług.

Wojewódzki Sąd Administracyjny w Bydgoszczy po rozpoznaniu na rozprawie w dniu 5 lutego 2020 r. sprawy ze skargi na interpretację indywidualną wydaną przez Dyrektora Krajowej Informacji Skarbowej w przedmiocie uznania Skarżącej za podatnika VAT oddalił skargę.

2. W glosowanym orzeczeniu WSA w Bydgoszczy postawił tezę, zgodnie z którą w zaistniałym stanie faktycznym uznał działania Skarżącej za przejaw aktywności profesjonalnej i zorganizowanej. Sprawa, której orzeczenie dotyczy, budzi wiele wątpliwości.

Trybunał Sprawiedliwości Unii Europejskiej (TSUE) po rozpoznaniu spraw połączonych C-180/10 i C-181/10 Jarosław Słaby i Emilian Kuć słusznie zauważył, że takie działania mogą zachodzić nie tylko w obrocie profesjonalnym, ale także prywatnym, wynikają bowiem $\mathrm{z}$ racjonalnego zarządzania majątkiem własnym i nie są charakterystyczne dla profesjonalistów. Należy zatem uznać, że podział nieruchomości na mniejsze działki i uzyskanie decyzji o warunkach zabudowy nie wystarcza, aby zaklasyfikować działania Skarżącej jako działań o charakterze profesjonalnym i zorganizowanym.

WSA w Łodzi w sprawie o sygn. I SA/Łd 777/19³ również zauważa, że działania sprzedającego nieruchomość zmierzające do podziału nieruchomości oraz uzyskania decyzji o warunkach zabudowy nie stanowią przejawu aktywności profesjonalnej i zorganizowanej, należy je bowiem uznać za racjonalny zarząd własnym majątkiem. Ponadto stan faktyczny sprawy, której dotyczy orzeczenie WSA w Łodzi sygn. I SA/Łd 777/19, jest podobny. Po pierwsze, obie sprawy dotyczą nieruchomości rolnej oraz sposobu jej wykorzystywania, po drugie, wszystkie koszty związane z podziałem nieruchomości i uzyskaniem decyzji o warunkach zabudowy Skarżący, podobnie do Skarżącej z glosowanego wyroku WSA w Bydgoszczy, poniósł z majątku prywatnego.

${ }^{2}$ Wyrok TSUE w sprawach połączonych C-180/10 i C-181/10: Jarosław Słaby, Emilian Kuć, Halina Jeziorska-Kuć v. Minister Finansów, Dyrektor Izby Skarbowej w Warszawie (Dz. Urz. UE C 319 z dnia 29 października 2011 r.).

3 Wyrok WSA w Łodzi z dnia 12 marca 2020 r., sygn. I SA/Ld 777/19, LEX nr 2923261. 
3. Sprzedający mający zamiar sprzedać nieruchomość stanowiącą jego własność musi w dostateczny sposób uzewnętrznić swój zamiar. W glosowanym orzeczeniu WSA w Bydgoszczy uznał korzystanie z usług biura pośrednictwa przy sprzedaży nieruchomości za przejaw aktywności profesjonalnej. Trudno zgodzić się z zapadłą w tym orzeczeniu tezą, sam bowiem fakt korzystania $\mathrm{z}$ usług profesjonalistów nie determinuje zakwalifikowania statusu sprzedającego jako podatnika VAT. Tego typu działanie sprzedającego charakterystyczne jest raczej dla obrotu prywatnego. Sprzedający, który działa przy pomocy pośrednika, nie zna dostatecznie dobrze rynku nieruchomości, dlatego trudniej jest mu osiągnąć ekwiwalentność świadczeń przy sprzedaży. Działania te należy zatem uznać za racjonalną aktywność w sferze zwykłego zarządu nieruchomością, charakterystyczną dla obrotu prywatnego, a nie profesjonalnego. WSA w Łodzi przychylił się do powyższego stanowiska w innym wyroku, z dnia 14 czerwca 2018 r. $^{4}$ Problematyczny jest, jak się wydaje, zakres dokonywanych czynności, gdyż sprzedający sam może działać jak profesjonalista, angażując w celu sprzedaży środki podobne do środków specjalistów, samo jednak korzystanie z usług biura pośrednictwa nie może przesądzać o uznaniu działań sprzedającego za aktywność profesjonalną i zorganizowaną. W sprawie, której dotyczy glosowany wyrok WSA w Bydgoszczy, działania Skarżącej o charakterze marketingowym niewątpliwie nie wpisują się w zakres czynności podejmowanych przez profesjonalistów, takich jak zamówienie usługi wykonania dokumentacji fotograficznej za pomocą drona, utworzenie specjalnej strony internetowej na potrzeby marketingu czy szeroko stosowane ogłoszenia sprzedaży.

4. Do czynników przemawiających za uznaniem podmiotu za podatnika podatku od towarów i usług przy sprzedaży nieruchomości należy zaliczyć również sposób i cel nabycia nieruchomości. W glosowanym orzeczeniu WSA w Bydgoszczy Skarżąca nabywała nieruchomości stopniowo i odpłatnie. Jakkolwiek odpłatność nabycia nieruchomości rzeczywiście może wpływać na kwalifikację podmiotu jako podatnika VAT, to jednak należy uznać, że bez zaistnienia pozostałych niezbędnych elementów determinujących status podatnika VAT sama w sobie nie przesądza o jego charakterze. Problematyka z tym związana jest w szczególności widoczna

${ }^{4}$ Wyrok WSA w Łodzi z dnia 14 czerwca 2018 r., sygn. I SA/Łd 174/18, LEX nr 2511130. 
obecnie, gdy w dobie ogłoszenia stanu epidemii na terenie RP oraz wobec zaistniałej sytuacji gospodarczej zdecydowanie większa część podmiotów prywatnych lokuje swoje oszczędności na rynku nieruchomości, bez zamiaru odsprzedaży, ale jedynie w celu niejako ochrony wartości zgromadzonego kapitału. Oczywiście odpłatność nabycia jest cechą, która przemawia za zakwalifikowaniem podmiotu po stronie podatnika VAT, niemniej sama w sobie nie przesądza o ostatecznym statusie osoby fizycznej, osoby prawnej lub jednostki organizacyjnej nieposiadającej osobowości prawnej na gruncie ustawy o podatku od towarów i usług.

Ważny jest również cel nabycia, lecz nie można domniemywać, że nieruchomość wykorzystywana w prowadzonej działalności gospodarczej została nabyta właśnie w tym celu. Wojewódzki Sąd Administracyjny w Szczecinie w wyroku z dnia 19 czerwca 2013 r. ${ }^{5}$ zauważa, że istotny jest moment nabycia nieruchomości oraz istnienie związku między poniesieniem wydatku na nabycie nieruchomości a prowadzoną działalnością opodatkowaną. Późniejsze faktyczne wykorzystywanie przez podatnika nieruchomości do celów działalności gospodarczej nie przesądza zatem o tym, że samo nabycie nastąpiło także $\mathrm{w}$ takim celu. W glosowanym orzeczeniu WSA w Bydgoszczy sąd nieprawidłowo powiązał moment nabycia nieruchomości z poniesieniem wydatku w tym celu, Skarżąca bowiem nabyła własność nieruchomości w celu prowadzenia gospodarstwa rolnego, a nie jej późniejszej odsprzedaży. Zgodnie z art. 15 ust. 1 ustawy o podatku VAT 6 oraz w związku z przedstawionym we wniosku do Dyrektora Krajowej Informacji Skarbowej stanem faktycznym Skarżąca nie podlega opodatkowaniu, ponieważ prowadzona przez nią działalność nie ma charakteru ciągłego i zarobkowego.

5. W glosowanym orzeczeniu WSA w Bydgoszczy nie wziął pod rozwagę braku działań uatrakcyjniających Skarżącej, które zmierzałyby chociażby do podniesienia wartości nieruchomości. Ich wystąpienie niewątpliwie wpłynęłoby na możliwość uznania Skarżącej za podatnika VAT. Do działań tych należy zaliczyć przede wszystkim prace ziemne, takie jak niwelacja terenu, utwardzenie gruntu, przyłączenie mediów czy ogrodzenie działek. W przedmiotowym orzeczeniu Skarżąca nie podjęła żadnych tego rodzaju

5 Wyrok WSA w Szczecinie z dnia 19 czerwca 2013 r., sygn. I SA/Sz 14/13, LEX nr 1339835.

${ }^{6}$ Ustawa z dnia 11 marca 2004 r. o podatku od towarów i usług (Dz.U. z 2020 r., poz. 106). 
działań, co powinno wpłynąć negatywnie na zakwalifikowanie jej statusu jako podatnika VAT, ponieważ takie właśnie działania wobec nieruchomości podejmują podmioty działające w sferze profesjonalnej. Sprzedająca tym samym nie zaangażowała środków podobnych do wykorzystywanych przez producentów, handlowców i usługodawców w rozumieniu art. 9 ust. 1 akapit drugi dyrektywy 2006/1127, zmienionej dyrektywą 2006/138 (dalej: dyrektywa VAT). Tym samym WSA w Bydgoszczy niesłusznie uznał działalność Skarżącej za przejaw aktywności profesjonalnej i zorganizowanej. Podobne stanowisko przedstawił Wojewódzki Sąd Administracyjny w Olsztynie w wyroku z dnia 15 grudnia 2011 r. ${ }^{9}$ Uznał bowiem, że Rzeczpospolita Polska jako państwo członkowskie nie skorzystała z możliwości uznania za podatnika VAT podmiotu okazjonalnie dokonującego transakcji związanej z działalnością, o której mowa w art. 9 ust. 1 akapit drugi dyrektywy VAT (w szczególności pojedynczej dostawy terenu budowlanego), a za którą bez wątpienia można uznać sprzedaż wszystkich części podzielonej nieruchomości.

6. Podsumowując, status prawny w sferze podatku od towarów i usług zależny jest od wielu czynników. Bez wątpienia można zaliczyć do nich nie tylko działania związane $\mathrm{z}$ podziałem nieruchomości gruntowej na mniejsze działki, dokonaniem czynności niezbędnych do wydania decyzji o warunkach zabudowy oraz sposobem sprzedaży. Działania te bez uwzględnienia innych składowych pojęcia podatnika VAT przy sprzedaży nieruchomości nie mogą decydować o uznaniu konkretnego podmiotu za podatnika VAT. Aby rzetelnie określić pojęcie podatnika podatku od towarów i usług, należy uwzględnić również inne czynniki, takie jak sposób i cel nabycia nieruchomości, działania uatrakcyjniające lub ulepszające nieruchomość oraz zarobkowy i ciągły charakter działalności. Glosowany wyrok WSA w Bydgoszczy został wydany na podstawie błędnej kwalifikacji

7 Dyrektywa Rady 2006/112/WE z dnia 28 listopada 2006 r. w sprawie wspólnego systemu podatku od wartości dodanej (Dz. Urz. UE L 347/1 z dnia 11 grudnia 2006 r.).

8 Dyrektywa Rady 2006/138/WE z dnia 19 grudnia 2006 r. zmieniająca dyrektywę 2006/112/WE w sprawie wspólnego systemu podatku od wartości dodanej w odniesieniu do okresu stosowania systemu podatku od wartości dodanej mającego zastosowanie do usług nadawczych radiowych i telewizyjnych oraz niektórych usług świadczonych drogą elektroniczną (Dz. Urz. UE L 384/92 z dnia 29 grudnia 2006 r.).

9 Wyrok WSA w Olsztynie z dnia 15 grudnia 2011 r., sygn. I SA/Ol 640/11, LEX nr 1150371. 
podjętych przez sprzedającą nieruchomość działań, jako przejawu aktywności profesjonalnej i zorganizowanej. Skład orzekający niesłusznie określił działalność Skarżącej w zakresie sprzedaży nieruchomości jako działalność gospodarczą o charakterze ciągłym i zarobkowym.

\section{Gloss to the Judgment of the Provincial Administrative Court in Bydgoszcz of 5TH February 2020, CASE No. I SA/BD 732/19}

Summary. The glossed judgment of the Provincial Administrative Court concerns mainly the scope of the concept of a VAT taxpayer when selling real estate and problems that arise in practice in connection with the actions taken by the seller. The author makes a critical analysis of the thesis put forward in the judgment and raises problematic issues related to the seller's activity in order to increase the value or make the property more attractive.

Keywords: VAT on the sale of real estate, the concept and premises of a VAT payer, professional and organized activity of the property seller 